\title{
A Comparative Study of Organizational Role Stress and Organizational Commitment Among The University Faculty Members of India and Saudi Arabia
}

\author{
Dr. Sayeeduzzafar Qazi \\ Professor College of Business Administration \\ University of Business \& Technology Jeddah, KSA \\ Dr. Afroze Nazneen
}

Asst. Professor- IHGI IKG Punjab Technical University. Jalandhar, India

doi: 10.19044/esj.2016.v12n31p108 URL:http://dx.doi.org/10.19044/esj.2016.v12n31p108

\begin{abstract}
Stress is define as a dynamic condition in which an individual is confronted with an opportunity, constraint, demand related to what he or she desires and for which the outcome is perceived to be both uncertain and important. Organizational role stress comes from three sectors i.e. job and organization, social factor and intra-psychic factor. Organizational commitment is defined as "an individual psychological bond to the organization, including a sense of job involvement, loyalty and belief in the values of the organization”. The cross cultural study was conducted on 245 Faculty members working in various Indian and Saudi Arabian universities using questionnaire method and standardized psychometric tests were used to collect the data on the variable under investigation. The study reveals that faculty members of Saudi Arabia were shown moderate level of organizational role stress and low level of organizational commitment while their Indian counterparts were shown high level of organizational role stress and moderate level of organizational commitment. The organizational role stress dimensions were found to be negatively correlated with organizational commitment means if the organizational role stress will go up the commitment level of the faculty members will go down and affect the performance of the faculty members negatively. The data were also analyzed using other demographic variables and the obtained results were discussed.
\end{abstract}

Keywords: Organizational Role Stress, Organizational Commitment, Cross Culture, Stress Audit 


\section{Introduction}

"Stress now a days considered as a big threat to the quality of life and to physical and psychological well-being.. The very idea of stress was introduced in 1936 by Hans Selye, who actually kind of borrowed it via natural sciences. "During the eighteenth and nineteenth centuries, stress was equated with force, pressure or strain exerted upon a material object or person which resists these forces and attempts to maintain its original state”. Hans's 'General Adaptation Syndrome’ provoked quite a lot of research on this topic, primarily focusing stress and disease, i.e., noxiousness to tissues systems and adaptation response to tissues systems.

Lazarus (1971) proposed what is essentially an interactional definition of stress. He suggested that "Stress occurs when there are demands on the person which taxes or exceeds his adjustive resources". He further elaborated that it depends not only on external conditions but also on the constitutional vulnerability of the person and the adequacy of his cognitive defensive mechanisms.

Similarly Cox and McKay (1981) suggested that stress arises when there is an imbalance between the perceived demand and person's perception of his capability to meet that demand. The system treats stress as an intervening variable, the reflection of transaction between the person and his environment.

\section{Organizational Role Stress}

In any social system, such as family, club, religious community, work organization etc., individuals has certain obligations towards the system, which in turn gives each one of them a defined place in the society. This system of mutual obligations can be called a role and the individual's place, a position or an office. It can be said that role is a very useful concept in understanding the dynamics of the integration of the individual with an organization. It also helps in understanding the problems which arises in this individual-organization interaction and integration. This would enable the individual to function effectively in an organization. Also role is, a central concept in work motivation ( Pareek, 1974). In other words, we can say that organizations have its own structures and goals. Similarly the individual has his personality and needs (motivation).

\section{Concept of Role Stress}

Kahn and others (1964) were the ones who drew attention towards organizational stress (in general) and particularly role stress. In their eyes, role stress was one of the variants of stress. Furthermore, variants like role overload, role ambiguity, and role conflict were a part of role stress. In short, 
any role expectation that exceeded the incumbent's resources could be named as role stress, according to them.

On the other hand, Pareek (1976) had something else to say. He defined stress to be inevitable, for there are always inherent problems in performance of any role. Furthermore, the concept of role space, role set, including the role itself as a whole, has an in-built potential for stress (and even conflict one can say). In fact, as the role is more or less and most of the times defined by the expectations of the role senders, the expectations on the other hand can remain ambiguous conflictive to each other, unless integrated, shared or articulated in right manner.

Pareek (1983) has identified the following role stresses:

\section{Role space conflicts}

Role space (the dynamic relationship amongst the various roles an individual occupies and his self) has three main variables: self, the role under question, and the other roles he occupies. Any conflicts may take the forms mentioned below:

1. Self-Role Distance: This pressure arises out of the disagreement between the self-concept and the outlook form the role, as supposed by the role, as apparent by the role tenant. If a person occupies a role which he may subsequently find as conflicting with his self concept, he feels stressed. For example, an introvert may experiences self-role distances if he accepts the job of a salesman which includes meeting people and being social.

2. Role Stagnation: An individual grows in the role that he occupies in an organization. With the advancement of the individual the role changes, and with this change in role, the need for taking up original role becomes vital. This trouble of role enlargement becomes sharp especially when a human being who has busy a position for a long time enters an additional role in which he may feel less secure. However, the new position demands that an individual outgrow the previous ones and take charge of the new role effectively. This is bound to produce some stress.

3. Inter-Role Distance: When an individual occupies more than one role, there are bound to be conflicts between the different roles that he occupies. For example, an air traffic controller often faces the conflict between his organizational role as an air traffic controller and his familial role as a husband and a father.

\section{Role set conflicts}

The other field which is important vis-à-vis an individual's role is the set which consists of important persons who have varying expectations from the role that he occupies. The conflicts which arise as a result of incompatibility amongst these expectations by the 'significant' others (and 
by the individual himself) are called role set conflicts (Pareek. 1983). These conflicts take the following forms:

1. Role Ambiguity: When the individual is not apparent about the various outlook that people have as of his position the conflict that he faces is called role uncertainty. Marshall and Cooper (1979) point out that role ambiguity exists when and person has insufficient information about his work role, that is, where there is 'lack of clarity' about the work colleagues' expectation of work role and about the scope and responsibilities of the job.

2. Role Expectation Conflict: When there are contradictory prospect or demands by different position senders, the role occupant may experience this stress. There may be conflicting expectations from the superior, subordinates, friends.

3. Role Overload: When the role inhabitant feels that there are too many expectations from the 'significant' other in his role set, he experiences role over load. Role overload is more likely to occur where role occupants lack power, where there are large variations in the expected output and when delegations or assistance cannot procure more time. French and Caplan (1973) have differentiated overload in term of 'qualitative' and 'quantitative' overload. Quantitative overload refers to having "too much to do." Qualitative overload means works that is "too difficult".

4. Role Erosion: A role inhabitant may feel that some functions which he would like to carry out are being performed by various other roles. The stress felt may be called role erosion. In other words, role erosion is the subjective feeling of the individual that some important role expectations he has from the role are shared by other roles within the role set. Pareek (1983) is of the view that role erosion is likely to be experienced in an organization which is redefining its role and creating new roles.

5. Resource Inadequacy: Resource insufficiency pressure is knowledgeable when the capital required by the role occupant for performing the role effectively is not available. These may be information, people, material, finance or facilities.

6. Personal Inadequacy: When a role occupant feels that he is not prepared to undertake the role effectively, he may experience this stress. The role occupant may feel that he does not have enough knowledge, skills, or training, or he/she has not had time to prepare for the assigned role.

7. Role Isolating: In this category, Pareek (1983) includes stressors which Marshall and Cooper (1979) identify as arising from nature of relationships at work. Pareek (1983) suggests that in a role set, the role occupant may feel that certain roles are psychologically closer to him, while others are at a much greater distance. The main criterion of distance is frequency and ease of interaction. He future suggests that when linkages are strong, the role isolation will be low and in the absence of strong linkages, 
the role isolation will be high. The gap between the desired and the existing linkages will indicate the amount of role isolation.

To sum up, Pareek (1983) identified the following ten stresses in relation to organizational roles:

1. Self-Role Distance (SRD) 2. Inter-Role Distance (IRD) 3. Role Stagnation (RS)

4. Role Isolation (RI) 5. Role Ambiguity (RA) 6. Role Expectation Conflict (REC)

7. Role overloads (RO) 8. Role Erosion (RE) 9. Resource Inadequacy (RIN)

10. Personal Inadequacy (PI)

\section{Organizational commitment}

O’Reilly (1989) defines organizational commitment as "an individual psychological bond to the organization, including a sense of job involvement, loyalty and belief in the values of the organization”. This perspective of organizational commitment is more characterized by the employee's acceptation of the organizational goals and his/her willingness to make effort on behalf of the organization to achieve those goals (Miller and Lee, 2001).

According to Cohen (2003), "commitment is a force that binds an individual to a course of action of relevance to one or more targets". This, however, is quite a general description and somewhat relates to the one given by Arnold (2005). Arnold described it as "the relative strength of an individual's identification with and involvement in an organization”.

Miller (2003) defines organizational commitment as “a state in which an employee identifies with a particular organization and its goals, and wishes to maintain membership in the organization”. Therefore, it can be reiterated as the degree to which the employee wants to be associated with the organization willingly, keeping in view the relationship with the organization's values and goals.

\section{Affective Commitment Dimension:}

The first that is taken is the affective commitment dimension. It can also be termed as emotional commitment. This represents the employee's emotional attachment with the organization he/she works for. Meyer and Allen (1997) explain the term affective commitment as "the employee's emotional add-on to, recognition with, and participation in the organization". According to this, the members who are really devoted to a certain organization emotionally continue to work for that organization, for they want to (Allen and Meyer, 1991). Emotionally devoted members continue to work for the organization for they feel that their personal goals and values 
are congruent to the organization's goals and values (Beck and Wilson, 2000).

Beck \& Wilson (2000) say that the development of affective commitment involves internalization and identification. An employee's emotional attachment with his/her organization is based on his identification with his wish to establish a honoring relationship with the organization. Furthermore, internalization refers to the congruency between the goals and values of individual and organization. Therefore, overall, per (Allen \& Meyer, 1990), emotional (or affective) organizational commitment is more so related to the individual's identification with the organization.

\section{Continuance Commitment Dimension}

Out of the three aforementioned dimensions, the second one is continuance commitment. It is explained by Meyer \& Allen (1997) as "awareness of the costs associated with leaving the organization". As the word 'cost' comes in, it obviously has a calculative nature, as the individual herein perceives the risks and costs attached if he decides to leave the current organization. The researchers (Meyer \& Allen, 1991) further say that "employees whose primary link to the organization is based on continuance commitment remain because they need to do so". Now, this very statement clearly differentiates the affective from continuance commitment.

According to Beck and Wilson (2000), continuance promise can be considered as an active attachment as here the association of the individual with the organization is based on the degree of appraisal or the degree of financial benefits. The commitment is developed towards an organization because of the optimistic external plunder received from side to side the effort-bargain lacking identification with the values and goals of the organization.

Their need to stay with the organization can be termed as 'profit' that they would continue to reap if they continue to be associated with the organization. On the other hand, this would directly change to 'cost' if they plan to leave the organization

\section{Normative Commitment Dimension}

Normative commitment stands as the last of the three dimensions as explained by the 3-dimsional model of organizational commitment. It is explained by Meyer \& Allen (1997) as "a feeling of obligation to continue employment”. Per Allen and Meyer (1990), interiorized normative beliefs of duty and responsibility make an individual grateful to affirm his membership in the organization. Meyer and Allen (1991) also believe that "employees with normative commitment feel that they ought to remain with the 
organization”. As far as normative dimension is concerned, employees generally do not leave the organization because they think it is good to do so.

Normative commitment as defined by Weiner and Vardi (1980) is "the work behavior of individuals, guided by sense of duty, obligation and loyalty towards the organization”. According to Iversion and Buttegieg (1999), ethical reasons motivate the organizational members to stay with the organization. An employee who adheres to norms and is committed towards the organization feels morally attached to the organization, irrespective of the job satisfaction or status enhancement is provided over the years by the organization.

\section{Literature review}

Hashemi, et al (2015) conducted a study to analyze the direct effect of the relationship between role stress and organizational commitment in the hospitality industry. Studies reviewed indicate that stress has important effects on personnel and organizational outcomes. Stress at the work place may result in unfavorable outcomes such as low level of performance and resignation from the job. Therefore, identifying the job stress's factors in an organization will significantly improve job satisfaction, which in turn strengthens staff's loyalty to the organization. Moreover, organizations need to acknowledge the contribution made by each employee in order to instill loyalty and a strong sense of belonging as well as reduce the tendency to resign from the organization.

Alipour and Kamaee (2015) explored that job stress may lead to organizational commitment, which is a vital factor for achieving organizational efficiency. Materials and The study was conducted on 120 nurses working in the hospitals of Behbahan. The results showed that there is a significant inverse relationship between job stress and organizational commitment. Moreover, there is a significant inverse relationship between job stress and affective, normative and continuance commitment.

Nazneen et al (2014) conducted a study on 350 top executives of public and private enterprises to check the level of organizational role stress and stress tolerance level. They found that top executives of private sectors are showing high level of organizational role stress and the dominant stressors are role erosion, role isolation and inter role distance while in the case of public sector enterprises top executives the level of organizational role stress is moderate and dominant stressors are the same as the case of private enterprises.

Nazneen \& Bhalla (2013 ) conducted a study on 220 faculty members of Public and Private Universities and found that faculty members of private universities are suffering with High level of Organizational Role Stress as compare to their Public Universities counterparts. The dominant role 
stressors found were role erosion, inter-role distance, role expectation conflict and personal inadequacy. While in the case of faculty members of public universities the dominant stressors are role erosion, resource inadequacy, role expectation conflict and role isolation. They further found that there are significant negative correlation among role stagnation and organizational commitment, role overload, role and ambiguity were also found to be significantly negative correlated with organizational commitment. They also found significant negative correlation between total organizational role stress and organizational commitment, means, if in any organization level of stress will go up the organizational commitment will go down and vise-versa.

Nazneen \& Bhalla (2013) conducted a study on 218 male and 132 female employees of organized retail sectors and found that the employees of organized retail sectors are suffering with high level of organizational role stress and dominant stressors are personal inadequacy, role erosion, role stagnation and inter role distance. They further found that male employees of organized retail sectors are showing high level of organizational role stress as compared to female employees.

Muncherjee and Pestonjee (2013) conducted a study to find out organizational role stress and emotional intelligence level of members of private bank. They conducted the study on 56 Tope Executives and found high level of organizational role stress among them and the dominant stressors were role over load, inter role distance, personal inadequacy and role erosion respectively.

Bhalla and Sayeed (2013) conducted a study on 150 executives of organized retail sector and found that the employees are suffering with high level of organizational role stress and the dominant stressors are role erosion, inter role distance, role expectation conflict and personal inadequacy and low level of organizational commitment. Further they found negative significant relationship between organizational role stress and organizational commitment.

Nazneen and Singh (2012) conducted a study on 126 faculty members of UPTU and PTU affiliated institutions and found that PTU faculty members are showing high level of organizational role stress than their PTU counterparts and dominant stressors are role erosion, role expectation conflict, inter role distance and role isolation.

\section{Objective of the study}

We have not formulated any Hypothesis and make our research Exploratory in nature and hence formulated following objectives: 
- $\quad$ To study the level of Organizational Role Stress and Job Commitment and its components among Faculty Members Working in Indian and Saudi Arabian University

- To examine the effect of Organizational Role Stress on organizational commitment.

- $\quad$ To suggest the Strategy to Stakeholders to overcome Stress and increase Organizational commitment and Job Satisfaction.

\section{Methodology}

The present research is directed to explore organizational role stress and organizational commitment among faculty members working in Indian and Saudi Arabian Universities. It was also proposed to determine the level of the said variables and the relationships between the organizational role stress and organizational commitment and their relationship with reference to certain demographic variables.

\section{Samples}

Thorndike (1979) proposed a rule or informal guide that "there should be ten respondent for each variable plus fifty respondents". And as per the guideline or the rule we should have $13 * 10+50=180$ respondents. Keeping this in view and availability of the data this study was conducted on 245 randomly selected faculty members out of which 155 Faculty members were from Indian Universities and 90 Faculty members from Saudi Arabia universities taken as sample of the study. The respondents were also divided on the basis of demographic variables.

\section{Procedure}

Faculty members from Management, Engineering and Information Technology departments of Indian and Saudi Arabian Universities were selected as a sample keeping in mind the availability of the data, cost and distance for the data collection. Only faculty members with more than two years of experiences were taken in to consideration. The data were collected using survey method. Each of the respondents was personally contacted in group by the investigator and the data was collected through questionnaire. They were asked to fill the questionnaire after going through carefully the given instructions on each scale separately. They were also assured of confidentiality of their responses.

\section{Tools Used}

The study was performed through questionnaire and following two standardized psychometric measures were used in this study and the details of them are as follows: 
Organizational Role Stress Scale developed by Pareek, (1983) was used, consists of 50 items and measure 10 type of role stressors. Each dimension of ORS is measured by five questions. The reliability and validity is well within acceptable norms:

Organizational Commitment Scale developed by Meyer and Allen (1997) were used to measure organizational commitment. There are 18 items in the scale, 6 each for Affective, Normative commitment and Continuance commitment. Reliability and validity found to be within acceptable norms.

The data obtained were statistically analyzed for all the ten dimensions of organizational role stress and three dimensions of organizational commitment separately for the comparison group and also on the dimensions of demographic variables which were also dichotomized. The data has been analyzed by using Systat- VII statistical package in terms of mean, median, standard deviation, critical ration and correlation between organizational role stress and organizational commitment Necessary adjustment were made, keeping in view their diametrically opposite scoring patterns and also to facilitate easy assimilation.

\section{Results and discussions}

TABLE 1: Showing Mean and SD Value on ORS and OC Dimensions among Faculty Members Working in Indian University. (N-155)

\begin{tabular}{|c|c|c|}
\hline VARIBLES & MEAN & SD \\
\hline INTER ROLE DISTANCE & 8.95 & 3.56 \\
\hline ROLE STAGNATION & 7.50 & 4.05 \\
\hline ROLE EXPECTATION CONFLICT & 8.29 & 3.992 \\
\hline ROLE EROSION & 8.07 & 3.576 \\
\hline ROLE OVERLOAD & 7.43 & 4.145 \\
\hline ROLE ISOLATION & 7.08 & 3.889 \\
\hline PERSONAL INADEQUACY & 7.21 & 4.143 \\
\hline SELF ROLE DISTANCE & 7.15 & 3.706 \\
\hline ROLE AMBIGUITY & 7.04 & 4.239 \\
\hline RESOURCES INADEQUACY & 8.02 & 3.269 \\
\hline TOTAL ORGANIZATIONAL ROLE STRESS & 76.74 & 28.10 \\
\hline AFFECTIVE & 16.17 & 3.028 \\
\hline CONTINUANCE & 15.18 & 2.773 \\
\hline NORMATIVE & 17.34 & 3.028 \\
\hline TOTAL COMMITMENT & 48.69 & 6.208 \\
\hline
\end{tabular}

Source: Compiled from primary data collected by questionnaire.

It is clear from the above Table that Faculty members of Indian universities are showing moderately high level of organizational role stress and dominant stressors are inter role distance means there is a conflict between organizational role and other roles and the faculty members are not 
able to divide the time between the organizational role and family role hence feeling stress. The second dominant stressors is role expectation conflict means faculty members are getting different demands from different people in the university and are not really aware about their actual role which leads to stress among them. The third dominant factor is role erosion means faculty members felt whatever important activity they are doing in the university the credit for the same are being taken by some one else in the university. The fourth dominant factor is resources inadequacy means they are feeling resource constraint or lack of basic resources to perform the given task effectively and hence felt stressed. The rest of the organizational role factors are within the acceptable range of tolerance.

As shown in the table that faculty members are showing a moderate level of organizational commitment and dominant type is normative commitment, followed by affective and continuance commitment supported the findings of Sharma (2015) who also reported moderate level of organizational commitment among university faculty members. The faculty are feeling sense of moral organization to remain in the organization and hence showing moderate level of commitment.

TABLE 2: Showing Mean and SD Value on ORS and OC Dimensions Among the Faculty Members Working in Saudi Arabian Universities. (N-90)

\begin{tabular}{|c|c|c|}
\hline VARIABLES & MEAN & SD \\
\hline INTER ROLE DISTANCE & 7.88 & 3.46 \\
\hline ROLE STAGNATION & 7.34 & 3.99 \\
\hline ROLE EXPECTATION CONFLICT & 6.75 & 3.96 \\
\hline ROLE EROSION & 8.03 & 3.54 \\
\hline ROLE OVERLOAD & 7.52 & 4.14 \\
\hline ROLE ISOLATION & 7.18 & 3.84 \\
\hline PERSONAL INADEQUACY & 6.01 & 4.16 \\
\hline SELF ROLE DISTANCE & 6.34 & 3.75 \\
\hline ROLE AMBIGUITY & 5.68 & 4.39 \\
\hline RESOURCE INADEQUACY & 6.69 & 3.22 \\
\hline TOTAL ORGANIZATIONAL ROLE STRESS & 69.05 & 30.12 \\
\hline AFFECTIVE COMMITMENT & 15.80 & 3.05 \\
\hline CONTINUANCE COMMITMENT & 17.64 & 2.96 \\
\hline NORMATIVE COMMITMENT & 14.78 & 3.16 \\
\hline ORGANIZATIONAL COMMITMENT & 51.22 & 6.75 \\
\hline
\end{tabular}

As shown in the Table that faculty members working in Saudi Universities are showing moderate level of organizational role stress and dominant stressor are role erosion means faculty members felt whatever important activity they are doing in the university the credit for the same are being taken by some one else in the university. The second dominant stressor 
is inter role distance means there is a conflict between organizational role and other roles and the faculty members are not able to divide the time between the organizational role and family role hence feeling stress. The third role stress is role overload means faculty members felt that lot much are being expected from them by the leadership than they cope with in the university which leads to work load and ultimately leading to stress. The fourth stressor is role stagnation means the faculty members are not seeing any opportunities for learning and growth in the organization.

It is also observed from the table that faculty members working in Saudi Arabian Universities are showing a moderately high level of organizational commitment and dominant type is continuance commitment, followed by affective and normative commitment supported the findings of Sharma (2015) who also reported moderate level of organizational commitment among university faculty members. The faculty members are showing high level of commitment because they felt that that leaving the organization is related with cost and since leaving the university could be a costly affair hence they are committed with the university.

TABLE-3 : Showing Z Value between the Faculty Members Working in Indian and Saudi Arabian Universities.

\begin{tabular}{|c|c|c|c|c|c|}
\hline \multirow{2}{*}{ VARIABLES } & \multicolumn{2}{|c|}{$\begin{array}{c}\text { India } \\
(\mathrm{N}-155)\end{array}$} & \multicolumn{2}{c|}{$\begin{array}{c}\text { Saudi Arabia } \\
(\mathrm{N}-90)\end{array}$} & \multirow{2}{*}{ CR } \\
\cline { 2 - 5 } & MEAN & SD & MEAN & SD & $2.32^{*}$ \\
\hline INTER ROLE DISTANCE & 8.95 & 3.56 & 7.88 & 3.46 & 0.30 \\
\hline ROLE STAGNATION & 7.50 & 4.05 & 7.34 & 3.99 & 0.96 \\
\hline ROLE EXPECTATION CONFLICT & 8.29 & 3.99 & 6.75 & 3.96 & $2.94^{*}$ \\
\hline ROLE EROSION & 8.07 & 3.57 & 8.03 & 3.54 & 0.08 \\
\hline ROLE OVERLOAD & 7.43 & 4.14 & 7.52 & 4.14 & 0.16 \\
\hline ROLE ISOLATION & 7.08 & 3.70 & 7.18 & 3.84 & 0.20 \\
\hline PERSONAL INADEQUACY & 7.21 & 4.14 & 6.01 & 4.16 & $2.19 * *$ \\
\hline SELF ROLE DISTANCE & 7.15 & 3.70 & 6.34 & 3.75 & 1.64 \\
\hline ROLE AMBIGUITY & 7.04 & 4.23 & 5.68 & 4.39 & $2.38^{*}$ \\
\hline RESOURCE INADEQUACY & 8.02 & 3.26 & 6.69 & 3.22 & $3.12^{*}$ \\
\hline TOTAL ORS & 76.74 & 28.10 & 69.05 & 30.12 & $1.98^{* *}$ \\
\hline AFFECTIVE & 16.17 & 3.02 & 15.80 & 3.05 & 0.92 \\
\hline CONTINUANCE & 15.18 & 2.77 & 17.64 & 2.96 & $06.42^{*}$ \\
\hline NORMATIVE & 17.34 & 3.02 & 14.78 & 3.16 & $6.24^{*}$ \\
\hline TOTAL COMMITMENT & 48.69 & 6.20 & 51.52 & 6.75 & $3.27^{*}$ \\
\hline
\end{tabular}

*: Significant at .01 level of significance

**: Significant at .05 level of significance

As shown in the Table It is found that Indian Universities Faculty members were exposed with high level of Organizational Role Stress as compare to their counterparts working in Saudi Arabian Universities and the differences were found to be significant at .05 level of significance. The 
significant differences of means were also found on the dimensions of Inter Role Distance, Role Expectation Conflict, Personal Inadequacy, Role Ambiguity and Resources Inadequacy of Organizational Role Stress. And in all cases Faculty members of Indian universities were shown high level of role stress than Saudi Arabian counterparts. It is also clear from the Table that Faculty members of Saudi Arabian universities were shown moderately high level of organizational commitment than the faculty members working in Indian universities and the difference were found to be significant at .01 level of significance. Continuance commitment were found to be high in Saudi Arabia university faculty member because they realize that leaving this university will be a costly affair and they may not get the kind of salary and other related financial benefits they are getting. While normative commitment were found high among Indian universities faculty members as it is related with moral obligation to remain in the university as compare to their Saudi Arabian university faculty members who are not committed morally but committed because of financial aspects and in both the cases the differences of means were found to be significant at .01 level of significance.

TABLE-4 : Showing Z Value between the Male Faculty Members Working in Indian and Saudi Arabian Universities.

\begin{tabular}{|c|c|c|c|c|c|}
\hline \multirow{2}{*}{ VARIABLES } & \multicolumn{2}{|c|}{$\begin{array}{c}\text { India } \\
(\mathrm{N}-80)\end{array}$} & \multicolumn{2}{c|}{$\begin{array}{c}\text { Saudi Arabia } \\
(\mathrm{N}-55)\end{array}$} & \multirow{2}{*}{ CR } \\
\cline { 2 - 5 } & MEAN & SD & MEAN & SD & C.9. \\
\hline INTER ROLE DISTANCE & 9.35 & 3.56 & 8.15 & 3.46 & $1.98^{* *}$ \\
\hline ROLE STAGNATION & 7.82 & 4.04 & 7.71 & 3.98 & 0.15 \\
\hline ROLE EXPECTATION CONFLICT & 9.21 & 3.99 & 7.32 & 3.97 & $2.75^{*}$ \\
\hline ROLE EROSION & 8.27 & 3.57 & 8.38 & 3.45 & 0.18 \\
\hline ROLE OVERLOAD & 7.59 & 4.14 & 7.61 & 4.41 & 0.02 \\
\hline ROLE ISOLATION & 7.12 & 3.88 & 7.71 & 3.84 & 0.88 \\
\hline PERSONAL INADEQUACY & 8.87 & 4.11 & 6.92 & 4.11 & $2.73^{*}$ \\
\hline SELF ROLE DISTANCE & 7.12 & 3.67 & 6.98 & 3.75 & 0.21 \\
\hline ROLE AMBIGUITY & 8.71 & 4.19 & 6.69 & 3.87 & $2.93^{*}$ \\
\hline RESOURCE INADEQUACY & 7.76 & 3.26 & 6.45 & 3.91 & $2.06^{* *}$ \\
\hline TOTAL ORS & 81.82 & 27.87 & 73.92 & 28.03 & 1.63 \\
\hline AFFECTIVE & 17.62 & 3.08 & 15.59 & 3.00 & $3.88^{*}$ \\
\hline CONTINUANCE & 15.34 & 2.75 & 17.53 & 2.97 & $04.43^{*}$ \\
\hline NORMATIVE & 16.95 & 3.03 & 14.01 & 3.17 & 5.46 \\
\hline TOTAL COMMITMENT & 52.91 & 6.24 & 47.13 & 6.74 & 5.11 \\
\hline
\end{tabular}

As it is clear from the Table that no significant differences between Means were found among the Male faculty members working in Indian and Saudi Arabian Universities on the total Organizational Role Stress but the differences were observed on the dimension of Inter Role Distance, Role Expectation Conflict, Role Ambiguity and Resources Inadequacy dimension 
of Organizational role Stress. And in all the mentioned cases Male faculty members were shown high level of stress than Saudi Arabian universities Male faculty members and the differences were found to be significant at .01 and .05 level of significance. Surprisingly Male Faculty members of Indian universities were shown High level of Organizational Commitment than Saudi Arabian universities Male faculty members and the dominant dimension were Affective and Normative while on the dimension of Continuance Commitment Male Faculty members of Saudi Arabian universities were shown high level of commitment that is associated with the Cost involved in leaving the university is very high hence showing commitment and be a part of the university.

TABLE-5: Showing Z Value between the Female Faculty Members Working in Indian and Saudi Arabian Universities.

\begin{tabular}{|c|c|c|c|c|c|}
\hline \multirow{2}{*}{ VARIABLES } & \multicolumn{2}{|c|}{ India } & \multicolumn{2}{c|}{$\begin{array}{c}\text { Saudi Arabia } \\
(\mathrm{N}-75)\end{array}$} & \multirow{2}{*}{ CR } \\
\cline { 2 - 5 } & MEAN & SD & MEAN & SD & CR \\
\hline INTER ROLE DISTANCE & 8.55 & 3.56 & 7.61 & 3.23 & 1.32 \\
\hline ROLE STAGNATION & 7.18 & 4.18 & 6.98 & 3.94 & 0.23 \\
\hline ROLE EXPECTATION CONFLICT & 7.37 & 3.79 & 6.18 & 3.84 & 1.48 \\
\hline ROLE EROSION & 7.87 & 4.26 & 7.69 & 3.76 & 0.21 \\
\hline ROLE OVERLOAD & 7.27 & 3.87 & 6.67 & 4.09 & 0.71 \\
\hline ROLE ISOLATION & 7.05 & 3.77 & 6.65 & 3.71 & 0.51 \\
\hline PERSONAL INADEQUACY & 5.56 & 4.31 & 5.11 & 4.01 & 0.52 \\
\hline SELF ROLE DISTANCE & 7.18 & 3.84 & 5.70 & 3.97 & 1.79 \\
\hline ROLE AMBIGUITY & 5.38 & 4.33 & 4.67 & 3.95 & 0.83 \\
\hline RESOURCE INADEQUACY & 8.26 & 3.32 & 6.93 & 2.88 & $2.09 * *$ \\
\hline TOTAL ORS & 71.67 & 31.23 & 64.19 & 27.54 & 1.23 \\
\hline AFFECTIVE & 14.72 & 2.86 & 16.01 & 2.98 & 1.09 \\
\hline CONTINUANCE & 15.02 & 2.37 & 17.76 & 2.76 & $05.02 *$ \\
\hline NORMATIVE & 17.74 & 2.80 & 15.56 & 3.76 & $2.99 *$ \\
\hline TOTAL OC & 47.48 & 5.10 & 49.33 & 5.76 & 1.59 \\
\hline
\end{tabular}

As it is clear from the Table that Female faculty members of Indian and Saudi Arabian university were not showing any significant dimension of all Organizational Role Stress dimensions except on Resources Inadequacy and Female faculty members of Indian Universities were having high level of stress because of lack of proper resources in executing their duties and responsibilities and the differences between the means were found to be significant at .05 level of significance. It was also found that there were no significant differences on organizational commitment and both country university faculty members were showing moderate level of organizational commitment. Female faculty members of Saudi Arabian Universities were showing high level of organizational commitment on the dimension of 
continuance commitment as compare to Indian female faculty members and the difference between means were found to be significant at .01 level of significance and this is because of the High Cost involved in leaving the university. While on the dimension of Normative commitment Female faculty members of Indian universities were shown high level of commitment as compare to Saudi Arabian universities Female faculty members and the differences between Mean were found to be significant at .01 level of significance and this high level of commitment among Female Indian universities faculty members were because they morally feel to be remain and committed in the university.

TABLE 6: Showing Correlation among ORS and OC Dimensions of Faculty Members working in Indian Universities.

\begin{tabular}{|c|c|c|c|c|}
\hline VARIABLES & AFFECTIVE & CONT & NORM & T.COMM \\
\hline IRD & 0 & 0.018 & $-0.31^{*}$ & -0.14 \\
\hline RS & 0.018 & -0.09 & $-0.36^{*}$ & -0.21 \\
\hline REC & -0.16 & -0.07 & $-0.29^{* *}$ & $-0.25^{* *}$ \\
\hline RE & -0.11 & -0.011 & $-0.29^{* *}$ & -0.2 \\
\hline RO & -0.06 & 0 & -0.15 & -0.04 \\
\hline RI & -0.03 & -0.1 & $-0.27^{* *}$ & -0.19 \\
\hline PI & -0.13 & -0.04 & $-0.36^{*}$ & $-0.26^{* *}$ \\
\hline SRD & -0.05 & 0.06 & $-0.21^{*}$ & -0.1 \\
\hline RA & -0.05 & -0.05 & -0.18 & -0.14 \\
\hline RIN & -0.08 & -0.07 & -0.12 & -0.13 \\
\hline T.ORS & -0.07 & -0.05 & $-0.33^{*}$ & $-0.21^{* *}$ \\
\hline
\end{tabular}

It is evident from the Table that Organizational role stress and its components are negatively correlated with organizational commitment and its dimensions. It means if the level of organizational role stress among the faculty members working in Indian Universities will go up the level of organizational commitment will go down. Similar results were found by Nazneen and Bhalla (2013) and they also reported similar phenomenon among the faculty members of Indian Universities. It is the responsibility of the university leadership to manage the organizational role stress at manageable level so that organizational commitment among faculty members should be induced to the upper limits, which will lead to high productivity and effectiveness among faculty members and they will be able to give the desired results in the form of effective teaching, researches, innovations and consultancies in to their respective fields. 
TABLE 7: Showing Correlation between ORS and OC Dimensions among Faculty Members Working in Saudi Arabian Universities.

\begin{tabular}{|c|c|c|c|c|}
\hline VARIABLES & AFF & CONT & NORM & OC \\
\hline IRD & -0.009 & 0.047 & $-.205^{* *}$ & -0.079 \\
\hline RS & 0.017 & -0.068 & $-.317^{* *}$ & $-.172^{* *}$ \\
\hline REC & $-.187^{* *}$ & -0.058 & $-.244^{* *}$ & $-.224^{* *}$ \\
\hline RE & -0.086 & 0.041 & $-.263^{* *}$ & $-.143^{* *}$ \\
\hline RO & 0.071 & 0.058 & -0.047 & $.035^{*}$ \\
\hline RI & -0.051 & -0.079 & $-.198^{* *}$ & $-.151^{* *}$ \\
\hline PI & $-.113^{*}$ & 0.034 & $-.311^{* *}$ & $-.181^{* *}$ \\
\hline SRD & -0.047 & $.116^{*}$ & $-.162^{* *}$ & -0.045 \\
\hline RA & -0.065 & 0.038 & -0.097 & -0.057 \\
\hline RIN & $-.141^{* *}$ & -0.011 & -0.062 & -0.097 \\
\hline ORS T & -0.076 & 0.015 & $-.245^{* *}$ & $-.142^{* *}$ \\
\hline
\end{tabular}

*: Significant at .01 level of significance.

**: Significant at .05 level of significance.

Source: Compiled from primary data collected by questionnaire.

As shown in the table that the faculty members working in Saudi Arabian universities were shown a negative correlation with organizational role stress and its components and organizational commitment and its components. It clearly means that, if the level of organizational role stress and its components will increase the level of organizational commitment of the faculty members will decrease, supported the finding of Nazneen and Bhalla (2013. IRD were found negatively correlated with normative commitment means if there were high gap between conflict demands of various roles, the obligation to remain in the organization will go down hence reducing the level of commitment. Hence it is the responsibility of the affiliated institutions to manage the organizational role stress at manageable level so that maximum organizational commitment among faculty members should be induced which will lead to high productivity and performance among faculty members.

\section{Conclusion and Suggestions}

Indian Universities Faculty members were showing high level of organizational role stress and dominant stressors are Inter role distance, role expectation conflict, role erosion and resources inadequacy while organizational commitment was found to be moderate with normative commitment as dominant commitment. While in the case of faculty members working in Saudi Arabian universities organizational role stress were found to be moderate with dominant stressors include role erosion, inter role distance, role overload and role isolation with moderately high level of organizational commitment and continuance and affective commitment were 
found to be dominant commitment. Faculty members of both countries universities differ significantly on organizational role stress and organizational commitment. Male faculty members of Indian universities are showing high level of organizational role stress but surprisingly also showing high level of organizational commitment while in the case of Saudi Arabian faculty members moderately low level of organizational role stress and organizational commitment were reported. While in the case of female faculty members of Indian and Saudi Arabian universities no significant differences were found on organizational role stress and organizational commitment. Negative correlation were found among the various dimensions of organizational role stress and organizational commitment means if organizational role stress will go high the organizational commitment of both country university faculty members will go low.

It is recommended that all the universities should have stress audit on routine basis so that the dominant stressors can be identified and suitable individual and organizational interventions can be made accordingly. The universities should have proper rules regulations and policies to create a congenial environment and must ensure that their rules regulations and procedures laid down must be strictly implemented so that the faculty members should feel comfortable. The universities must ensure that their faculty members are attending faculty development programme at least once in a year related to their field of specialization. Universities must ensure that the faculty members are engaged in teaching, research and academic administration related work only. All universities should ensure proper pay package to the faculty members to avoid their exploitation and must induce element of job security. Proper career programs should be implemented in all the universities. These recommendations if implemented, may be helpful to reduce stress level among the faculty members and may ensure high level of organizational commitment among the faculty members.

\section{References:}

1. Alipour F, Kamaee Monfared M. (2015), “Examining the Relationship between Job Stress and Organizational Commitment among Nurses of Hospitals”, Patient Saf Qual Improv, 3(4):277-280.

2. Arnold, J. 2005. Work Psychology: Understanding Human Behaviour in the Workplace, 4th edition. London: Prentice Hall Financial Times.

3. Beck, N. \& Wilson, J. 2000. 'Development of affective organizational commitment: A cross sequential examination of change with tenure', Journal of Vocational Behaviour, 56: 114-136.

4. Bhalla,P.\& Nazneen,A(2013), "A study of organizational culture in indian organized retail sectors", International Journal Of Business Management and Research, Issue 4,pp 1-6 
5. Bhalla.P \& Zafar, S (2013), “A study of ORS and Organizational Commitment in Organized Retail Sector", Research Journal of Economics and Business Studies with ISSN No 2251-1555. Sept. 2013.

6. Hashemi, S. M., Jamil Jusoh, Kiumarsi, S. and Shno Mohammadi, (2015) "Exploring the role of stress on organizational commitment among employees in hospitality industry: the mediating role of job satisfaction”, International Journal of Information Research and Review. Vol. 2, Issue, 09, pp.1144-1150.

7. Cohen A. ( 2003): "Multiple Commitments in the work place: An integrative Approach” Mahwah, NJ, Lawrence Earlbaum Associates

8. Cohen, A.(2009): “ Commitment Before and After- A reconceptualization of organizational commitment”. Hum. Res. Management Review (17), pp 336-354.

9. Cox, T. And Mackay, C.J. (1981): “ A transactional Approach to Occupational Stress”. In E.N. Corlett and J. Richardson (Eds.), Stress, Work Design and Productivity, pp 91-113, New York: Wiley.

10. French, J.R.P. and Caplan, R.D. ( 1973): “ Organizational Stress and Individual Strain”. In A.J.

11. Ivancevich, J.M. and Matteson, M.T.(1984): “ A type-A-B-personwork environment Interaction Model for Examining Occupational Stress and Consequences”. Human Relations, 37, 491-513.

12. Iverson, R. D. \& Buttigieg, D. M. (1999): “ Affective, normative and continuance commitment: Can the 'right kind' of commitment be managed?” Journal of Management Studies, 36 (3), p. 307-333.

13. Kahn, R.L., Wolfe, D.M., Quinn, R.P., Snoek, J.D. and Rosenthal, R.A. (1964) Organizational Stress - Studies in Role Conflict and Ambiguity. NewYork: Wiley.

14. Lazarus, R.S. (1971): “ The concept of Stress and Disease.” In L. Levi 9Ed.) Society, Stress and Disease, pp53-58. London, oxford University Press.

15. Marshall, J. and Cooper, C.L. ( 1979): Executives Under Pressure- A Psychological Study. London: McMillan Press.

16. Miller, K. 2003. 'Values, attitudes and job satisfaction' In Robbins, S.P., Odendaal A. \& Roodt, G. (eds), Organisational Behaviour: Global and Southern African Perspectives. Cape Town: Pearson Education South Africa.

17. Meyer, J. P. and Allen, N. J. (1987), “Organizational commitment: Toward a three-component model”, Research Bulletin No. 660. The University of Western Ontario, Department of Psychology, London. 
18. Meyer, J.P. and Allen, N.J.(1991), “ A three component conceptualization of organizational commitment”. Human Resource Management Review, 1(1), pp 61-98.

19. Meyer, J.P., Allen, N.J. and Smith, C.A. (1993), "Commitment to organization and occupations: extension and test of a three component model", Journal of Applied Psychology, Vol. 78, pp. 53851.

20. Meyer, P.J., Stanley, D.J., Herscovitch, L. and Topolnytsky, L. (2002): “Affective, Continuance \& Normative Commitment to the organization: A meta analysis of the antecedents, correlates and consequences”, Journal of Vocational Behaviour, 61, pp-20-52.

21. Nazneen,A \& Bhalla,P. (2013), "A Comparative Study of ORS and Job satisfaction among male and female employees of Organized Retail Sector", International Journal Of Business Management and Research”vol3, Issue 4 pp 19-28.

22. Nazneen,A \& Bhalla,P. (2013), “A Study of Organizational Role Stress in Indian Retail Sector”, International Journal Of Management Research and Reviews Vol 3/Issue 7.

23. Nazneen,A \& Bhalla,P. (2014), "A study of ORS and among the Faculty members of Private and Public University", International Journal Of Human Resource Management and Research, vol 3 issue 4 pp-17-25.

24. Nazneen. A, Bhalla, P. and Singh, N. ( 2014): “A Comparative study of ORS, Stress Tolerance Level and its Management among the top executives of Indian public and private enterprises". Paper published in International Journal of Business, Management \& Research, Vol. 4, Issue 3, 85-94.

25. O'Reilly, C. 1989. 'Corporations, culture and commitment', California Management Review, 31: 9-24.

26. Pareek, U (1976): “ Inter Role Exploration “. In J.W. Pfeiffer and J.E. Jones ( Eds.), The 1976 Annual Handbook for Group Facilitators, pp.211-224, La Jolla: University Associates.

27. Pareek, U. ( 1983): Organizational role Stress Scale. ORS Scale Booklet, Answer Sheet and Manual. Ahmedabad: Navin Publications.

28. Pareek, U.( 1974): “A conceptual Model of Work Motivation." Indian Journal of Industrial Relations, 10 91), 15-31.

29. Pestonjee, D.M. ( 1993): Stress and Coping- The Indian Experience. New Delhi, Sage Publication.

30. Porter, L.W. (1968): Management attitudes and performance. Irwin: Homewood, 50-58. 
31. Suryawanshi , S.A. and Mali, V. J., (2013), "A study on Relationship between Organizational Role Stress and Job Satisfaction”, Indian Journal Of Research, Volume : 2 | Issue : 2

32. Selye, H. ( 1956): The Stress of Life. New York: McGraw Hill.

33. Tang, J. L.,(2008), "A Study of Work Stress, Organizational Commitment, Job Satisfaction, and Organizational Citizenship Behavior: A Case to Employee Who are Taking Further Education in University", The Journal of Human Resource and Adult Learning Vol. 4, Num. 1.

34. Vanishree, P. (2014), "Impact of Role Ambiguity, Role Conflict and Role Overload on Job Stress in Small and Medium Scale Industries", Research Journal of Management Sciences ,ISSN 2319-1171 Vol. 3(1), 10-13

35. Wiener, Y., \& Vardi, Y. (1980). Relationships between job, organization, and career commitments and work outcomes-an integrative approach. Organizational Behavior and Human Performance, 26, 81-96. 